\title{
FALSE ELEVATION OF FREE THYROXINE AND TRIIODOTHYRONINE DUE TO THE PRESENCE OF ANTIBODIES TO IODOTHYRONINES
}

\author{
IYODOTIRONIN OTOANTIKORLARI SEBEBI ILLE YALANCI YÜKSEK TIROKSIN VE \\ TRIIYYODOTIRONIN DÜZEYLERI
}

\author{
Orkide KUTLU*, Caecilie Crawley LARSEN**, Solomon Maximo GREENBERG**, Alfonso \\ Massimiliano FERRARA**, Ferda Sevimli BURNIK***, Samil ECIRLI***, Samuel \\ REFETOFF**, Cevdet DURAN***
}

\begin{abstract}
The prevalence of autoimmune thyroid disease (AITD) has progressively increased. Circulating autoantibodies associated with AITD may affect the result of laboratory analyses and cause incorrect conclusions in the assessment of thyroid hormone status. In this report, we present a patient with Hashimoto's thyroiditis with high thyrotrophin and free thyroxine (T4) and triiodothyronine $\left(\mathrm{T}_{3}\right)$ levels due to the presence of auto-antibodies to iodothyronines. Free $\mathrm{T}_{4}$ and free $\mathrm{T}_{3}$ levels measured by direct immunometric assays method were high, while those estimated by measurement of the serum $\mathrm{T}_{4}$-binding capacity were low. L-thyroxine replacement therapy was started. In patients with discrepant laboratory results, interference from autoantibodies should be considered.

Key words: Thyroxine auto-antibody; hypothyroidism; false high free thyroxine; triiodothyronine levels.
\end{abstract}

\section{ÖZET}

Otoimmun tiroid hastalığı prevalansı giderek artmaktadır. Otoimmun tiroid hastalığı ile ilişkili otoantikorlar laboratuvar sonuçlarını etkileyebilmekte ve tiroid hormon durumunu değerlendirmede yanılmalara sebep olabilmektedir. Burada iyodotironin otoantikorları sebebi ile serbest tiroksin $\left(T_{4}\right)$, triiyodotironin $\left(T_{3}\right)$ ve TSH düzeyleri yüksek bir hasta sunduk. Direkt immunometrik yöntemlerle ölçülen free $T_{4}$ ve $T_{3}$ düzeyleri yüksek olmasına rağmen, serum $T_{4}$ bağlama kapasitesi ölçümü ile tahmin edilen değerler düşük olduğundan hastaya L-tiroksin replasman tedavisi başlanmıştır. Bu çalışmada; nadir karşılaşılan free $\mathrm{T}_{4}, \mathrm{~T}_{3}$ ve TSH düzeylerinde tutarsızlık/uyumsuzluk bulunan hastalarda ayırıcı tanı olarak iyodotironin otoantikorlarına bağlı otoimmun tiroid hastalığı görülebileceği vurgulanmıştır.

Anahtar kelimeler: Tiroksin otoantikoru; hipotiroidi; yalancı yüksek serbest tiroksin; tiriiodotironin düzeyleri; otoimmun tiroidit.

\section{INTRODUCTION}

The prevalence of autoimmune thyroid disease (AITD) has progressively increased $(1,2)$. The most common cause of AITD is Hashimoto's thyroiditis. In this condition, thyroid peroxidase (TPO), thyroglobulin (TG), and rarely, thyrotropin (TSH) receptor blocking antibodies, as well as antibodies to iodothyronines can be detected $(1,2,3,4)$. In rare situations, free $T_{4}\left(F_{4}\right)$ and free $\mathrm{T}_{3}\left(\mathrm{FT}_{4}\right)$ levels, measured by routine automated immunometric methods, can give false results $(5,6,7,8)$. In this article, a biochemically hypothyroid patient with high $\mathrm{TSH}, \mathrm{FT}_{4}$ and $\mathrm{FT}_{3}$ levels due to antibodies against the iodothyronines is presented.

\section{SUBJECTS AND RESULTS}

A 59-year old female patient presented to our outpatient clinic with symptoms of fatigue and exhaustion. Previous laboratory analysis showed high serum levels

Date received/Dergiye geldiği tarih: 08.01.2016 - Date accepted/Dergiye kabul edildiği tarih: 01.02.2016

* Okmeydani Training and Research Hospital, Department of Internal Medicine,

** Department of Medicine, The University of Chicago, Chicago, IL, USA

*** Division of Endocrinology and Metabolism, Department of Internal Medicine, Konya Training and Research Hospital, Konya, TURKEY

(Corresponding author/İletişim kurulacak yazar: orkidekutlu@windowslive.com) 
of $\mathrm{TSH}, \mathrm{FT}_{4}$ and $\mathrm{FT}_{3}$. These laboratory abnormalities persisted for at least 6 years. Her blood pressure was $130 / 80 \mathrm{mmHg}$, heart rate $86 \mathrm{pulse} / \mathrm{min}$ and regular, temperature $36.5^{\circ} \mathrm{C}$. She had a grade $2 / 6$ systolic ejection murmur and a trace amount of pretibial nonpitting edema. Also, she has been found to have type 2 diabetes mellitus and hypertension for 12 years. Family history was negative except for diabetes mellitus. Laboratory analyses showed a TSH of $29.6 \mu \mathrm{IU} / \mathrm{ml}$ (normal range 0.35-5.5 $\mu \mathrm{IU} / \mathrm{ml}$ ), $\mathrm{FT}_{4} 3.56 \mathrm{ng} / \mathrm{dl}$ (normal range $0.74-1.79 \mathrm{ng} / \mathrm{dl}$ ), FT3 $>40 \mathrm{pg} / \mathrm{ml}$ (normal $2.3-4.2$ $\mathrm{pg} / \mathrm{ml}$ ). Magnetic resonance imaging (MRI) was not compatible with a TSH secreting pituitary adenoma. TRH test was performed and after the administiration of $400 \mu \mathrm{g}$ Protelin, intravenously, TSH and prolactin levels increased to $46.9 \mu \mathrm{IU} / \mathrm{ml}$ and $59.3 \mathrm{ng} / \mathrm{dl}$ at 30th $\mathrm{min}$, respectively. At 60th minute, $\mathrm{TSH}$ and prolactin levels were found to be $34.2 \mu \mathrm{IU} / \mathrm{ml}$ and $27.3 \mathrm{ng} / \mathrm{ml}$, respectively. The possibility that the patient might have resistance to thyroid hormone (RTH) or to TSH was considered. Sequencing of the THRB and TSH receptor genes showed no abnormalities.

After obtaining written consents, blood samples were collected from the patient and first degree relatives for further testing as approved by the Institutional Review Board. TPO and TG antibodies were detected (Fujirebro, Japan) in the serum of the proband (I-4) indicating the presence of AITD. As shown in figure 1, she also had low total $\mathrm{T}_{4}$ and reverse $\mathrm{T}_{3}\left(\mathrm{rT}_{3}\right)$ measured by the Elecsys (Roche, Indianapolis, IN) platform and low free $\mathrm{T}_{4}$ index, $\left(\mathrm{FT}_{4} \mathrm{I}\right)$ estimated by measuring the serum $\mathrm{T}_{4}$-binding capacity. The latter measurements suggested hypothyroidism, a diagnosis confirmed by a high serum TSH concentration. Antibodies to $\mathrm{T}_{4}, \mathrm{~T}_{3}$ and $\mathrm{rT}_{3}$ were also identified by precipitation with polyethylene glycol radioiodinated tracers of these iodothyronines added to the subject's serum. These antibodies were not detected in her unaffected brother (I-3) (Fig. 1).

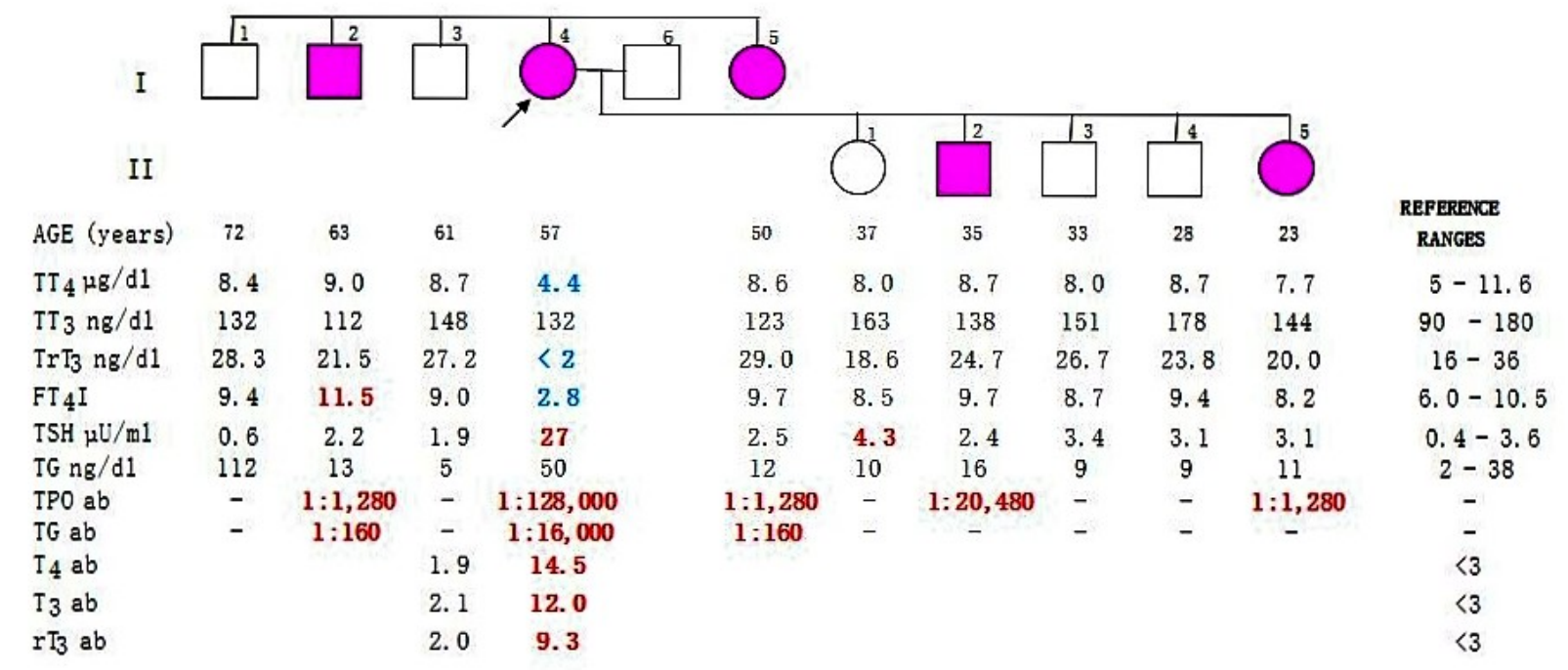

Figure 1: Pedigree of the family including thyroid function tests and circulating antibody levels. Females are represented by circles and males by squares. The proband is indicated with an arrow. Test results are aligned with each symbol. Abnormal values are represented in bold numbers; high in red and low in blue.

Four first degree relatives, two siblings (I-2 and I-5) and two of their children (II-2 and II-5) had also AITD based on the presence of TPO antibodies (Fig. 1). All had normal tests of thyroid function, except for a mild increase in the $\mathrm{FT}_{4} \mathrm{I}$ in her brother (I-2; Fig. 1).

Treatment of the proband with L-thyroxine was initiated and the dose was adjusted according to her serum TSH levels. Serum free hormone levels were not taken into consideration for dose adjustement. Nine months later, on $75 \mathrm{mcg}$ of L-thyroxine, TSH level was $2.74 \mathrm{mU} / \mathrm{L}$.

\section{CONCLUSIONS}

We report herein a patient with Hashimoto's thyroiditis and high free $T_{4}$ and $T_{3}$ levels due to $T_{4}$ and $T_{3}$ autoantibodies. In recent years, the prevalence of the AITD has been increasing worldwide and these autoantibodies may affect laboratory analysis and cause difficulties in assessing the thyroid status. In autoimmune thyroiditis, the iodothyronines within the thyroglobulin molecule behave as haptens bound to a carrier and thus elicit an immune response to generate antibodies $(8,9)$. Antibodies develop against the specific iodothyronine epitopes in the TG molecule. It has been reported that the incidence of $\mathrm{T}_{4}$ or $\mathrm{T}_{3}$ autoantibodies is $1.8 \%$ (10) and that these autoantibodies can coexist with TPO autoantibodies (11). Erregragui et al. reported that autoantibodies against the hormone-forming site included in P3 peptide of thyroglobuline (12). Depending on the immunometric method being used these antibodies can result in free and total iodothyronine levels that are falsely high or low $(4,5,6,7,13)$. In our patient, this led to the suspicion of TSH producing adenoma, RTH and resistance to TSH, all having been excluded by specific tests.

In patients with discrepancies in the clinical status and thyroid function tests, iodothyronine auto-antibodies 


\section{Iodotironin otoantikorlart}

should be measured. If present, TSH levels should be used to adjust the hormone replacement dose.

\section{CONFLICT OF INTERESTS}

The work was supported in part by grants R37DK15070 and 5M01RR04999 from the National Institutes of Health. The content is solely the responsibility of the authors and does not necessarily represent the official views of the National Institutes of Health

\section{REFERENCES}

1. McLeod DS, Cooper DS. The incidence and prevalence of thyroid autoimmunity. Endocrine 2012;42:252-265

2. Cooper DS, Ladenson PW. The thyroid gland. In: Gardner DG, Shoback D (Eds).

3. Greenspan's Basic and Clinical Endocrinology, 9th edition. New York (Printed in China): Mc Graw-Hill Company 2011;163-226

4. Plengvidhya N, Sunthornthepvarakul T, Vannasaeng S. Antitriiodothyronine antibody in patient with Hashimoto's thryoiditis. J Med Assoc Thai 1997;80:202-6

5. Staeheli V, Vallotton MB, Burger A. Detection of human anti-thyroxine and antitriiodothyronine antibodies in different thyroid conditions. J Clin Endocrinol Metab 1975;41:669-675

6. Ikekubo K, Konishi J, Endo K, et al. Anti-thyroxine and anti-triiodothyronine antibodies in three cases of Hashimoto's thyroiditis. Acta Endocrinol 1978;89:557-566

7. Abraham R, Chawla R. Interference of anti-T3 autoantibodies in the measurement of total and free $\mathrm{T} 3$ in serum. Indian $\mathrm{J}$ Clin Biochemistry 1997;12:40-44

8. Desal RK, Bredenkamp B, Jiala I, Omar MAK, Rajput MC, Joubert SM. Autoantibodies to thyroxine and triiodothyronine. Clin Chem 1988;34:944-946

9. Li Calzi L, Benvenga S, Battiato S, Santini F, Trimarchi F. Autoantibodies to thyroxine and triiodothyronine in the immunoglobulin $\mathrm{G}$ fraction of serum. Clin Chem 1998;34:2561-2562

10. Keffer JH. Preanalytical considerations in testing thyroid function. Clin Chem 1996;42:125-134

11. Sakata S, Matsuda M, Ogawa T, Takuno H, Matsui I, Sarui H. Prevalence of thyroid hormone antibodies in healthy subjects. Clin Endocrin 1994;41:365-370

12. Konishi J, Yasuhiro L, Kaisawa T, Ikebuko K, Nakayawa T Torizuka K. The effect of antithyroxine autoantibodies on radioimmunassay of free thyroxine in serum. Clin Chem 1982;28:1389-1391

13. Erregragui K, Cheillan F, Defoort JP, Prato S, Fert V. Autoantibodies to thyroid hormones: the role of thyroglobulin. Clin Exp Immunol 1996;105:140-147

14. Thacker EL, Refsal KR, Bull RW. Prevalence of autoantibodies to thyroglobulin, thyroxine, or triiodothyronine and relationship of autoantibodies and serum concentrations of autoantibodies and serum concentrations of iodothyronines in dogs. Am J Vet Res 1992;53:449-453 